ISSN 1813-5420 (Print). Енергетика: економіка,технологіï, екологія. 2018. № 3

used to determine the main factors for forming a model for analysis and prediction of electrical loads of energy market objects.

Key words: factor analysis, principal component method, power consumption system, schedule of electrical loads.

\title{
References
}

1. Rosen, VP / Application of the method of the main components for identifying the impact of indicators on the level of electricity consumption. Scientific and technical journal Electrotechnical and computer systems. / VP Rosen, Ya.M. Democrat // Odessa - 2017. - Issue 25 (10). - P. 199-205.

2. Ivakhnenko, VM The course of economic analysis. Tutorial / VM Ivakhnenko - 3rd edition revised and supplemented. - Kyiv: Knowledge-Press, 2002. - 190s.

3. Tolkachov, D.O. Application of the method of the main components for assessing the competitiveness of the enterprise / D.O. Tolkachev - Donetsk National University. - Donetsk

4. Zagreb, MM Theoretical aspects of the use of factor analysis in the analysis of the dynamics of the financial state of the enterprise / M.M. Zagreb - Scientific works of the Kirovohrad National Technical University. Economic sciences. - Kirovograd :, 2014. - 455-461s.

5. Khalafyan, AA STATISTICA 6. Statistical analysis of data: Textbook / A.A. Khalafyan [3rd ed.]. - M .: OOO "Beinom-Press", 2007. - 512 p.

6. Andrienko, V.M. Statistical methods for the analysis of economic indicators / V. M. Andrienko, M. G. Samysko [Electronic resource]. - Access mode: http://www.rusnauka.com/11_EISN_2008/Economics/ 30352.doc.htm.

7. Kim, J.-O. Factor, discriminant and cluster analysis / J.-O. Kim, Ch.U. Mueller, U.R. Cleck per. from english - Moscow: Finance and Statistics, 1989 - 608s.

8. Yankova, AG Multi-dimensional analysis in the STATISTICA / AG system Yankovaya - Extract 2. Odessa: Optimum, 2001.- 216 p.

9. Iberla, K. Factor Analysis [Text] / K. Iberla. - M .: Statistics, 1980 - 398 p. 1975 - 488s.

10. Lapitsky V.I. Organization and planning of environments: Textbook / VI Lapitsky M .: "Out. School »,

Надійшла 19.09.2018

Received 19.09.2018

V. Vasylenko, assistant, ORCID 0000-0001-7282-6459

National Technical University of Ukraine «Igor Sikorsky Kyiv Polytechnic Institute»

\section{TECHNOCENOLOGICAL APPROACH AND PROBLEM OF ENERGY EFFICIENCY IMPROVEMENT}

The article considers the problems of efficient use of energy resources and the problems of rational use of energy from energy consumers is justified, because the existing energy saving potential is quite large. The question of application of the technocenological approach for optimal management of energy consumption with the use of rank analysis, which includes procedures of interval estimation, parametric rationing, forecasting and standardization of consumption of resources is considered.

As a mathematical apparatus, a rank analysis is used, which refers to the method of researching the technocenosis of energy consumption, which implies further optimization based on the criteria of the form of hyperbolic $H$-distributions. The paper presents an algorithm for conducting rank analysis for forecasting power consumption and technocenose optimization. The practical example of technocenose optimization is presented and the rank-parametric distribution of technocenosis is shown on the parameter of electric consumption.

Key words: energy efficiency, technocenosis, rank analysis, optimization of technocenosis.

Introduction

The basis of energy conservation in power systems is the planned implementation of a complex of technical

(C) В.I. Василенко, 2018 


\section{ISSN 1813-5420 (Print). Енергетика: економіка, технології, екологія. 2018. № 3}

and technological measures and optimization of energy consumption of their individual elements at the system level. The purpose of optimization is to streamline the energy consumption of the power system objects, to save energy resources received from the consumed primarily through organizational measures, as well as to create scientifically grounded assumptions for conducting targeted energy surveys, followed by the implementation of technical and technological measures for energy conservation [1].

In order to ensure the reliability, efficiency of global and local energy supply systems, developing traditional and new sources of energy, it is necessary to minimize energy transmission losses on to users, to produce and effectively distribute the finite (electromechanical, thermal, etc.) types of energy for different areas of consumption and flexibly and efficiently use energy from the end-user. In future, the need for energy resources will only grow, and only the balance, the ratio of traditional non-renewable and alternative renewable energy sources will change [2].

The factors that determine the appropriateness of radical transformations in energy are as follows [3]:

- the emergence and development of new technologies, devices and materials, which are used in the field of production of various types of energy, and, at first, the pace and scale of development of computer and information technology;

- development and implementation of Smart Grid technology;

- the intensive growth of the number of small generators (first of all, non-traditional and renewable) energy sources in the world;

- general tendency to increase the level of automation of processes;

- threatening level of equipment wear;

- reduction of the overall level of reliability of power supply;

- high level of losses in the transformation, transmission and distribution of energy resources;

- the need to reduce the negative impact on the environment;

- the need to increase energy efficiency and energy conservation.

The problem of raising the level of energy efficiency is not new for Ukraine. In the new, harsh conditions of confrontation with the Russian Federation, when the prices for imported energy resources are dramatically increasing and their supply is limited, the urgency of the solution of the energy efficiency problem increases significantly. The lack of significant diversification of imports of natural gas and nuclear fuel puts energy resources as a priority task, which depends on the reliability of the functioning and even survival of the entire country. To a large extent, the solution to this problem depended on the implementation of energy efficiency measures in the regions, at specific enterprises, including housing and communal services enterprises, from the possibility of organizing and supporting activities in the field of energy efficiency by regional and local authorities. Unfortunately, a significant level of centralization of power in the country, as well as the lack of sufficient financial resources that could be used by local authorities, considerably limits its ability to implement energy-efficient regional policy, does not allow itself to determine the priorities for allocating resources for the implementation of measures, besides which always not enough [4].

Legal regulation in the field of energy saving and energy efficiency is based on the following principles [5]:

1) efficient and rational use of energy resources;

2) support and stimulation of energy saving and energy efficiency improvement;

3) systematic and comprehensive implementation of energy saving and energy efficiency measures;

4) energy saving planning and energy efficiency improvement;

5) the use of energy resources, taking into account resource, production and technological, environmental and social conditions.

Describing processes in the energy system, we use the following definitions (Fig.1):

1) technical power system (TPS) - the summation of numbers of equipment and enterprises that interact with each other for the production, consumption or transformation, storage, transportation or processing of energy products;

2) energy product - finished product, which is used mainly for the production of mechanical work.

Natural resources are used as inputs to TPS, in other words the summation of equipment and enterprises, the main outputs of which are products and services, but which also produce by-products and emissions. Natural resources of other energy sources such as solar radiation, tidal energy, geothermal energy, wind and heat are also used for direct conversion into mechanical, thermal or electrical energy.

Products that are outputs of the technical power system are inputs to other technical power systems or are used to provide services. At the end of their exploitation, they are reused within the technosphere or returned to the environment as emissions. Thus, inputs to the technosphere are natural resources, and the outputs of services provided to society, emissions and operational influences [6, 7]. 


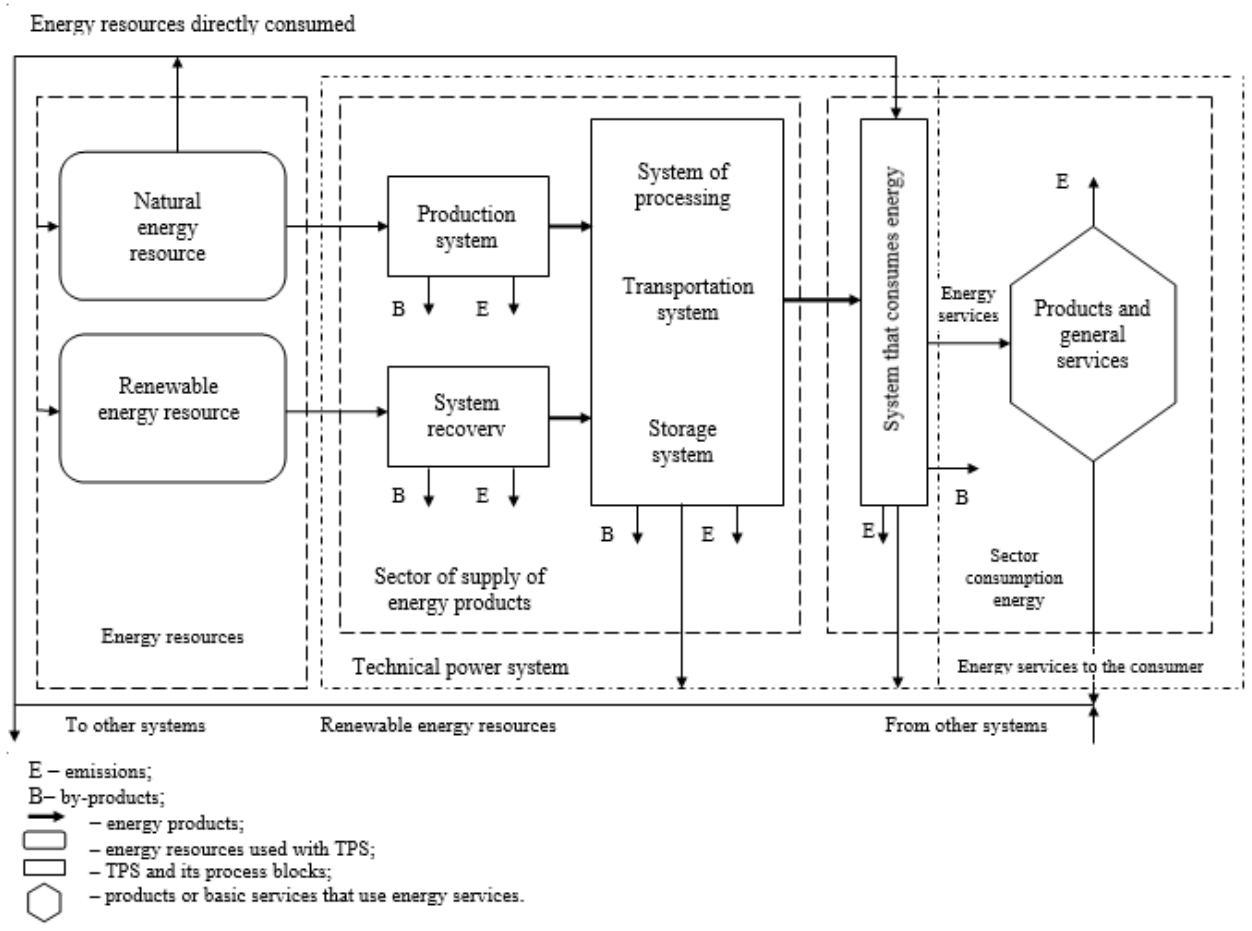

Figure 1 - The general model of the technical power system

\section{Methodology}

Currently, there are several methodologically different approaches to the description of the statistical structure of texts and other multicomponent objects. Such studies were initiated by the works of V. Pareto, J. Ula, J. Willis, J. Zipf, B. Mandelbrot (late XIX - first half of the XX centuries), who researched a similar type of distribution, representing the sharp unevenness of the number of objects. Despite the inadequacy of the approximation for individual sections of the empirical distribution curve, the Zipf rank distribution was the most well-known (hyperbole, or, as it is called in the leading Russian school of B.I. Kudrin, the distribution) $[8,9$, $10,11]$.

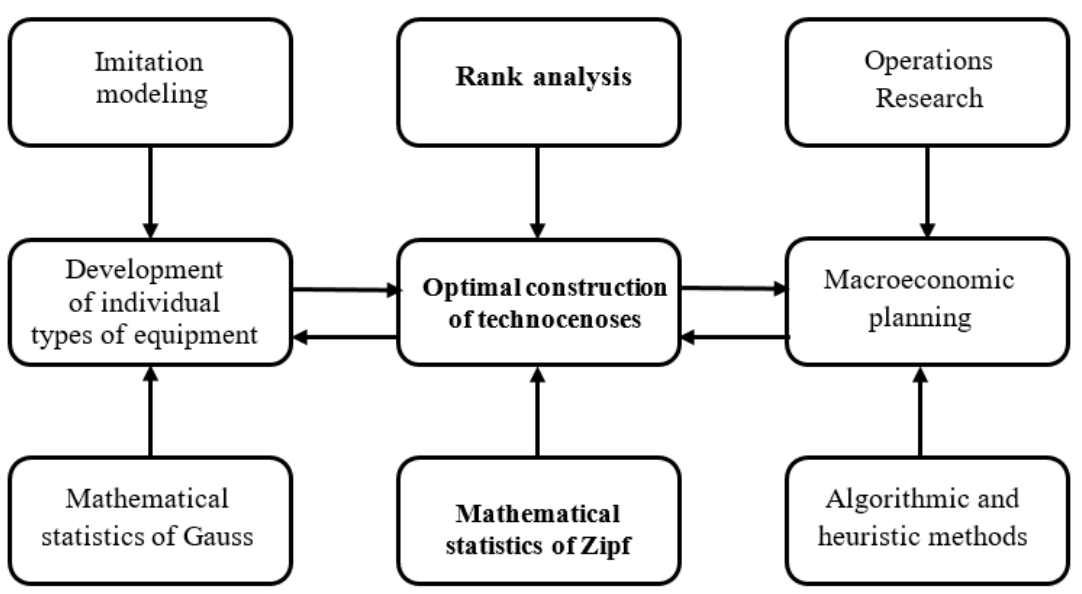

Figure 2 - Levels of research in the field of energy saving TPS

The general methodology of research and implementation in the field of energy conservation, according to the classification introduced in [12,13], can be conditionally divided into three levels (Fig. 2):

1) The first level corresponds to activities aimed at specific technical and technological developments that contribute to reducing energy consumption (improvement of heat supply systems, replacement of outdated lighting 


\section{ISSN 1813-5420 (Print). Енергетика: економіка, технологї, екологія. 2018. № 3}

devices, introduction of energy-efficient frequency controlled electric drives, modernization of internal equipment of buildings and structures, etc.).

2) At the second level, optimization of energy consumption of TPS as a whole is carried out. As a methodological basis at this level, a rank analysis based on the technocenological approach, Zipf mathematical statistics and the theory of hyperbolic infinitely divisive distributions is widely used. Given the conceptual and methodological differences that underlie research at the second level, it is considered to be systemic in relation to the level of research relating to specific technical and technological solutions in the field of energy conservation [14].

3) Strategic planning and forecasting of the TPS is carried out at the third level of activity (maneuvering of the maximum load, reduction of losses in the lines, effective control, etc.).

Real management of technocenosis is possible only in the conditions of correct understanding the object of management, as well as the introduction of correct methods for optimal management of this object.

The following terminology is used to describe the technocenosis [15]:

- individual - an integral part of the cenosis - are personified TPS, which carry out unique activities, have an individual name, are taxpayers, independently distribute and consume resources;

- view - a group of elements, systematized by the nature of the activity, size;

- population - a group of individuals of the same species;

- caste - a group in which each species is represented by an equal number of individuals.

The main properties of technocenosis [16]:

1) the name and number of all available (winding transformer wire, fasteners, tools, instruments, etc.) cannot be listed. Each of the objects is discretely allocated as an individual, but at the same time it can be described by a variable parameter (costs, electricity consumption) from a continuous series of positive integers. The discreteness and finiteness of the elements forming the technocenose, as well as the continuity and possible change of the cenosis parameter in general, allow it to be formalized to describe it for evaluation of the past, management of the current state and forecast of development;

2) uncertainty of the boundaries of electricity supply. They are not limited only to the master plan: own electric networks go beyond its limits, which feed on third-party consumers (the same thing - inside).

Speaking about the indicators that characterize the technocenosis (regardless of their verbal or formal representation), one should bear in mind:

1) the price cannot be adequately described by a system of indicators, any system is fuzzy and incomplete, an increase in the number of indicators and an increase in accuracy (reliability) does not approach to the selection of the technocenosis;

2) two cenoses, described by one system of indicators, which coincide within the limits of accuracy adopted for this class, may differ in essence (characteristics, parameters, representations).

Technocenosis has the following pronounced specific properties [12, 13, 17]:

1) interconnectedness - the individual objects of technocenose are statistically significantly related to a single system, but the type of connections in this case is special - these are so-called "weak" connections that are not reduced to the Newton's law, Ohm's law, Kirchhoff's law et al.;

2) "Gaussless" - statistical samples of the parameters of individuals (objects) have Zipf properties (the dependence of the mean and variance on the sample size is significant), that is, the law of large numbers is not executed, which consists in the fact that the average statistical value should converge on the probability of mathematical expectation. This suggests that, before starting to manage the infrastructure object, it is necessary to find out whether it is a technocenosis and, consequently, in general, whether it is possible to apply it to the technocenological methodology.

The main instrument of the technocenological approach in the study of complex technical systems is the rank analysis - the method of research of large technical systems (infrastructure), which aims at their statistical analysis, as well as optimization, and uses the form of generic and rank distributions as the main criterion. Hyperbolic $H$ - distributions are used to describe technocenosis.

Ranked distribution refers to the downward sequence of parameter values, arranged in such a way that each subsequent number is smaller than the previous one, and is brought into line with the rank (number in order, number of integers, arranged in ascending order) [3].

The structure of the cenosis is described by species distribution - the dependence of the number of species on the number of individuals in the form, ranked species distribution and rank distribution by parameter [15].

The mathematical apparatus of the cenological method is represented by three models of hyperbolic $H$ distribution $[1,16]$.

1) Species:

$$
\Omega(x)=\frac{W_{0}}{x^{1+\alpha}},
$$


ISSN 1813-5420 (Print). Енергетика: економіка,технологї̈, екологія. 2018. № 3 where $x \in(1 ; \infty]-$ a continuous analogue of population numbers $i$ ( $i$-always a discrete value, $i=[x]) ; a \succ 0$ - characteristic index; constant distribution $\gamma=1+a ; W_{0}=A \cdot S, W_{1}=\left[W_{0}\right]$, where $W_{0}$ - the theoretical discrete value, and $W_{1}$ - actual (experimental) value of the first point; $A$ - constant distribution, which is found from the conditions of valuation.

2) Ranked:

$$
\Lambda(x)=\frac{B}{r^{\beta}}, \omega(r)=\frac{\boldsymbol{u}_{r}}{U}, U=\sum_{r=1}^{S} u_{r}
$$

where $u_{r}$-the number of species of species (the population of the $S_{r}$ species), which corresponds to rank $r$ in the total number of individuals $U$. Rank of the species $s=1,2, \ldots, s_{r}, \ldots, S-$ is a serial number (line number). $1 \succ B \succ 0, \beta \succ 0-$ constants of a rank-like $H$-distribution.

The species and rank distribution are used to study and manage the structure of installed equipment and equipment that is being repaired (electrical installations), that is, for discrete quantities. But the power supply system is characterized by continuous quantities (electricity consumption, heat consumption, capacity, cost, costs). In this case, the hyperbolic rank $H$-distribution by parameter [18] is used.

3) Ranked by parameter.

Let's take a look a lot of objects that form a certain integrity (all units of a single enterprise) and which correspond to cenological criteria. Each object is characterized by one or more parameters that are expressed numerically. After defining the parameter, you can arrange the set, placing all objects in order of decreasing the parameter, and obtain a hyperbolic rank $H$-distribution by parameter. The area under the curve of the rank $H$ distribution by parameter characterizes the energy consumption of the enterprise as a whole:

$$
W(x)=\frac{W_{1}}{r^{\beta}},
$$

where $r$-the rank of the object; $\beta$ - an indicator that determines the degree of steepness of the distribution curve; $W_{1}=W_{\max }(x)-$ the constant for which the maximum value of the energy consumption of the largest consumer is taken.

$$
\beta=\log _{r} \frac{W_{1}}{W(x)} .
$$

The ranking by parameter allows us to talk about the optimality, the effectiveness of the cenosa as a whole. It is necessary to investigate the structure of the cenosis. Parameter $\beta$ varies within diapason $0,5 \ldots 1,5$ and determines the condition of technocenosis.

Removal of abnormal variations in the species distribution is based on the analysis of deviations from the approximating curve: upwards - indicate a lack of unification of species, and downward - on the contrary. Parametric optimization determines the detailed mechanism of the process of improving the structure of the cenosis on the basis of characteristic indicators.

The energy consumption of a separate TPS using a technosenological approach is considered not separately but correlated with other consumers, hierarchically systematized. Detection of the tendency of the electricity consumption of the power system of the region, analysis of the parameters of rank distributions creates the basis for optimizing the management of the electricity consumption of the infrastructure region, enabling more accurately predict the further development of the energy complex, assess its stability [19].

Investigating cenosis as an integrity reduces to their systematic description of the hierarchical system of indicators (which is necessary for the identification of the cenosis) and to the structural cenological description. Consider the technocenosis of the TPS on the example of the specific energy consumption by technoenese individuals. This cenosis is limited in space - the total number includes many functionally isolated individuals, not connected with each other by strong ties. There is also a single infrastructure that includes a power supply system, as well as a control system for operation and operation.

\section{Results and Discussion}

Energy consumption of the power system is described by analytical dependence: 


$$
W(x)=\frac{W_{1}}{r^{\beta}}=\frac{501316,2}{r^{0,725}} \Rightarrow \beta=0,725 .
$$

According to the above expression, one can determine some range of optimal states of the system and graphically display it as a certain band on the rank distribution graph (Fig. 3).

Fig. 3 shows that the specific power consumption is not optimal enough and needs to be significantly improved. The parameter of the $H$-distribution is not within the range, the energy consumption curve is far removed from the optimal approximation curve, which indicates the inadequate performance of the system as a whole. Needed additional work with technocenose: nomenclature optimization; purposeful removal of abnormal individuals; parametric optimization; improvement of parameters of abnormal individuals, etc.

Rank analysis never ends with the approximation of the relevant technocenose distributions. It always follows optimization, because our main task is to determine the directions and criteria for improving the existing technocenose. The procedure for optimizing any cenosis is aimed at eliminating abnormal deviations in rank distribution. After the detection of anomalies in the graphical distribution of the tabulated distribution, individuals are identified, "responsible" for the anomaly, and identified the priority measures to eliminate them.
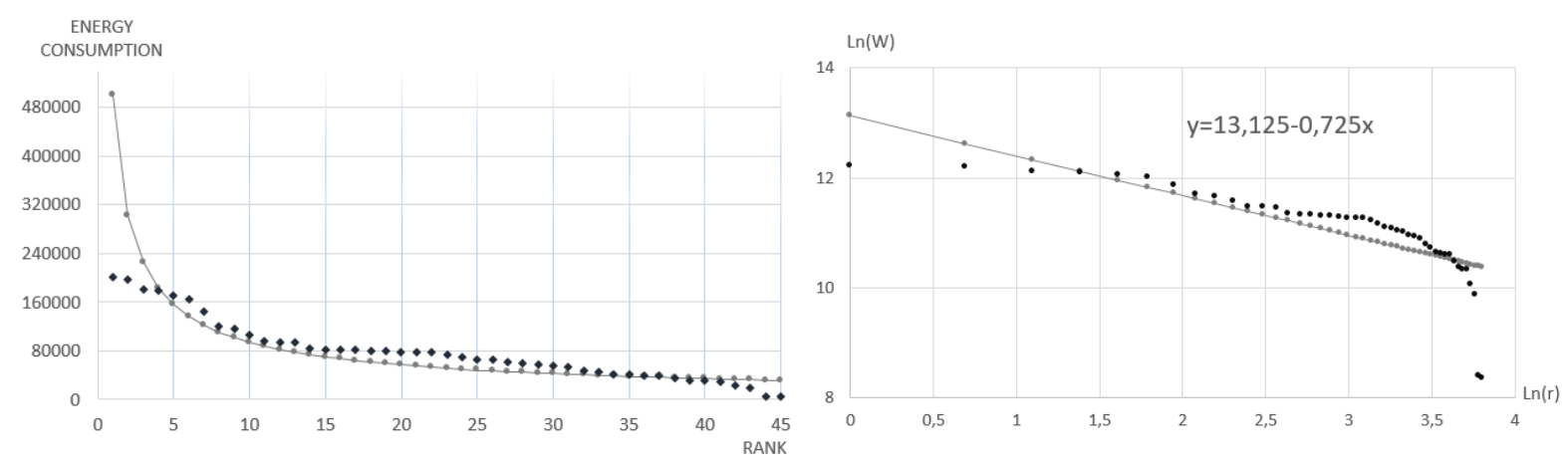

Figure 3 - The parametric distribution of the technocenosis of the TPS:

points - empirical data, solid line - approximation curve

The algorithm for conducting rank analysis for optimizing technocenosis includes the following steps.

1 . Selection of the cenosis.

Selection of technocenosis is accompanied by its description. For this purpose, a special database is provided, which includes systematized and standardized, sufficiently complete and at the same time, without unnecessary details, information on the types and individuals of technocenosis.

2. Setting of the shaping parameters.

Elements technocenose are allocated on the basis of the database. For each item there must be some documentation in the database. If we consider the case with TPS, then the database should contain data on monthly energy consumption.

3. Ranking - parametric description of the cenosis.

The first rank is assigned to an object with the highest energy consumption, further decreasing.

4. Construction of the tabulated rank distribution and the graphical rank parametric distribution of the existing technocenosis.

5. Calculation of the degree of steepness of the hyperbolic $H$-distribution curve. Approximation of distributions.

6. Optimize the technocenosis.

The best known technocenosis, which is a set of technical products, individuals who, on the one hand, their combined functional parameters provide performance tasks, and on the other - has a maximum entropy, so the total energy resources embodied in technical products for their manufacturing, distributed evenly according to the populations types of equipment. Optimal improvement of the structure proposed tehnotsenozu carried out in two phases: the first phase to determine and optimize the basic types, and the second - to form a species diversity of species and parameters of technical products that meet the requirements dictated by law optimal construction technocenosis.

After this analysis it is possible to proceed with the forecasting of energy consumption on the basis of technocenological approach. The block diagram of the algorithm for conducting rank analysis for the optimization of technocenosis is presented in the Fig. 4. 


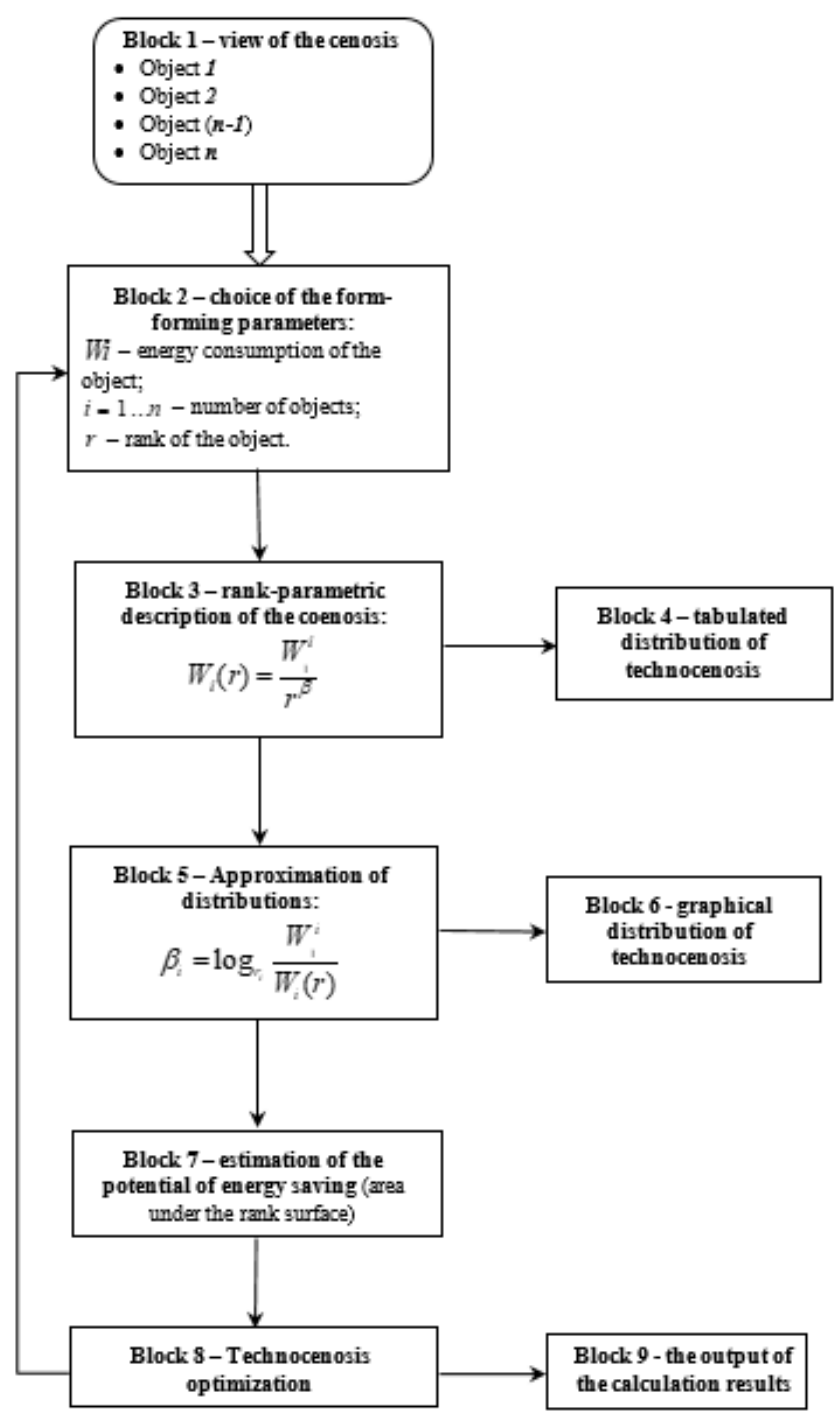

Figure 4 - Block-diagram of algorithm for conducting rank analysis for optimization of technocenosis

\section{Conclusions}

In this article the technocenological approach is applied in a new context. The algorithm for conducting rank analysis for optimization of technocenosis proposed by the author can help to choose the best energy conservation measures on technocensis objects without the need for energy audits.

The advantage of technocenological method and rank analysis is the optimal reflection of the process of functioning of technocenous objects in the future, taking into account possible changes in technology, infrastructure, and the use of resources. It is a disadvantage to note that the method based on a statistical model, as well as similar methods, with high accuracy calculates the value of short-term forecasting (according to studies, the exact forecast can be obtained for 1 to 2 years, after which the error is sharply increasing). Another disadvantage is the inability to implement criteria based on comparing power management options. These disadvantages can be eliminated. This requires the creation of a dynamic adaptive model that reflects the process of power consumption at a depth of 5 to 7 years or more.

This algorithm can be widely used for solving actual tasks of design, construction and operation of power systems, as well as for improving the quality and reliability of energy supply and implementation of energy saving measures, as well as new projects in the field of alternative energy.

\section{References}

[1] Vasylenko V. System efficiency of functioning of the power system with controlled loads. Power engineering: economics, technology, ecology. Vol. 1, 2015, p. $70-81$.

[2] Krichevsky G. The dangers and risks of nanotechnology and the principles of control over nanotechnology and nanomaterials // Nanotechnologies and health protection. Vol. 3, 2010, p. $10-24$. 
[3] Kobec B., Volkova I. Innovative development of electric power based on the concept of Smart Grid. - M.: IAC Jenergija, 2010. - 208 p.

[4] Shevtsov, A. Energy efficiency in the regional dimension. Problems and perspectives [Electronic resource]: analytical report / A/ Shevtsov, V. Barannik, M. Zemlyanny, T. Ryausov. - Dnipro: National Institute for Strategic Studies, 2014 - 78 p. - URL: http://www.niss.gov.ua/articles/1616//

[5] Energy Efficiency and its contribution to energy security and the 2030 Framework for climate and energy policy : Communication from the Commission to the European Parliament and the Council: COM (2014) 520 final, Brussels, 23.07.2014 [Electronic resource] - Mode of access: https://ec.europa.eu/energy/sites/ener/files/documents/2014_eec_communication_adopted_0.pdf

[6] ISO 13600-2001 Power engineering systems. Basic provisions (ISO 13600: 1997, IDT).

[7] ISO 13601-2001. Power engineering systems. Structure for analysis. Energy Supply and Consumption Sectors (ISO 13601: 1998, IDT).

[8] Schrader Y. Set Theory and Systems Theory // System Studies: Yearbook, 1978, p. 149 - 165.

[9] Shelukhin O., Belyakov I. Negauss processes. Sankt Peterburh: Polytekhnyka. 1992, 312 p.

[10] Kudrin B. Mathematics of Cenoses: Specific, Rank, Rank Parameter Hyperbolic H-Distributions and Lotka, Zipf, Pareto, Mandelbrot Laws // Cenological Studies. Vol. 19, 2002. p. 357 - 412.

[11] Zipf G. K. The psycho-biology of language. Boston, 1935. 336 p.

[12] Technique, technosphere, energy saving [Site] / V. Gnatyuk - Electronic text data. - M.: [BI], [2000 - 2013]. - Mode of access: http://www.gnatukvi.ru.

[13] Gnatyuk V. Law optimal construction technocenoses / V.I. Gnatyuk. - Issue 29. Tsenologicheskie study. - Moscow: Publishing House of the Tbilisi State University - Center for Systems Research, 2005. - 384 p.

[14] Prokopchik V. Improvement the quality of power supply and efficiency of electrical equipment of enterprises with continuous technological processes. Gomel, 2002.

[15] Kudrin B. Power supply for industrial enterprises: a textbook for students of higher educational institutions. Moscow, 2005.

[16] Kudrin B. Tsenological bases of management by an electric economy of the consumer. Industrial power. Vol. 9,2015 , p. $38-46$.

[17] Denisyuk S., Vasilenko V. Optimal management of energy consumption of budget organizations and institutions as objects of technocenosis. Bulletin of the Kiev National University of Technology and Design. Series Technical Sciences, Vol. 5 (114), 2017, p. 97 - 105.

[18] Kosharnaya Y. Use of methods of cenological and cluster analysis in energy audits of industrial enterprises. Proceedings of the VII International Scientific and Practical Internet Conference "Energy and Resource Saving XXI Century". Orel, 2009

[19] Fedorova S., Tretyakov A. Application of the technocenosis approach to the analysis of power consumption and energy concervation of the Sverdlovsk Region enterprises. Bulletin of the South Ural State University. Vol. 16, 2012, p. $92-97$.

В.I. Василенко, асистент, ORCID 0000-0001-7282-6459 Національний технічний університет України «Київський політехнічний інститут ім. Ігоря Сікорського»

\section{ТЕХНОЦЕНОЛОГІЧНИЙ ПІДХІД ТА ПРОБЛЕМИ ПІДВИЩЕННЯ ЕНРЕГТИЧНОЇ ЕФЕКТИВНОСТІ}

Обтрунтовано проблеми ефективного використання енергоресурсів та проблеми раціонального використання енергоспоживання, оскільки існуючий потенціал енергозбереження досить великий. Розглянуто питання застосування техноценологічного підходу для оптимального управління енергоспоживанням з використанням рангового аналізу, щуо включає в себе процедури інтервального оцінювання, параметричного нормування, прогнозування та стандартизації споживання ресурсів.

Як математичний апарат використовується ранговий аналіз, який відноситься до методу дослідження техноценозу енергоспоживання, щчо передбачає подальшу оптимізацію на основі критеріїв форми гіперболічних Н-розподілів. Представлено алгоритм проведення рангового аналізу для прогнозування споживання енергї та оптимізащіі техноценозу. Наведено практичний приклад 
ISSN 1813-5420 (Print). Енергетика: економіка,технологї, екологія. 2018. № 3 оптимізації техноценозів $i$ показаний рангово-параметричний розподіл техноценозу по параметру споживання електроенергії.

Ключові слова: енергоефективність, техноценоз, ранговий аналіз, оптимізація техноценозу.

Надійшла 24.10.2018

Received 24.10.2018

М. К. Безродний, д-р. техн. наук, проф., ORCID 0000-0002-0788-5011

С. О. Ословський, ORCID 0000-0003-2223-0248

Національний технічний університет України

«Київський політехнічний інститут імені Ігоря Сікорського»

\title{
ЕНЕРГОЕФЕКТИВНІСТЬ ТЕПЛОНАСОСНО-РЕКУПЕРАТОРНӦ̈ СИСТЕМИ ВОДЯНОГО ОПАЛЕННЯ І ВЕНТИЛЯЦЇ̈ 3 ВИКОРИСТАННЯМ ТЕПЛОТИ ГРУНТУ ТА ВЕНТИЛЯЦЙНИХ ВИКИДІВ
}

\begin{abstract}
Розглянуто комбіновану теплонасосно-рекуператорну схему водяного опалення $i$ вентиляції 3 використанням теплоти трунту та вентиляційних викидів. Виконано термодинамічний аналіз схеми теплопостачання, на основі якого визначені температурні параметри у вузлових точках системи, питомі затрати зовнішньої енергї̈ на одиницю виробленої теплоти на вході в об 'єкт опалення та вентиляції та частку теплового навантаження, щчо покривається трунтовим теплообмінником. Побудовано та проаналізовано графічні залежності критеріїв ефективності від величин, щзо визначають умови роботи схеми. Проведено співставлення отриманих критерїв енергоефективності з відповідними значеннями для традииійної теплонасосної системи з трунтовим теплообмінником.
\end{abstract}

Ключові слова: тепловий насос, вертикальний грунтовий колектор, низькотемпературне опалення, вентиляційні викиди, теплота грунту, термодинамічна ефективність.

Вступ

На даний час теплонасосна технологія отримання теплової енергії $є$ загально визнаною альтернативою в вирішенні проблеми економії енергії та підвищення енергоефективності традиційного теплогенеруючого обладнання. Завдяки відомим перевагам широкого розповсюдження у світі в системах теплопостачання різних об'єктів набули, зокрема, теплові насоси з використанням теплоти грунту. Однак, в Україні такі системи досі не набули широкого використання з цілого ряду причин, однією з яких є досить великі стартові капіталовкладення та високий рівень окупності, що для грунтового теплового насосу становить в середньому 5-7 років [1]. Тому актуальними на даний час є роботи в напрямку підвищення енергоефективності таких систем, що може сприяти зменшенню як експлуатаційних, так і початкових капітальних затрат на спорудження теплового насоса і грунтового теплообмінника. Відповідні задачі можуть бути вирішені шляхом розробки комбінованих теплонасосних систем 3 використанням окрім теплоти грунту додаткових низькотемпературних джерел енергії [2,3].

Конкретні можливості для розробки і впровадження в роботу таких нових схем виникають при розгляді та рішенні питань опалення та вентиляції широкого класу об'єктів, серед яких школи, лікарні, дитячі садочки, торговельно-розважальні комплекси, виробництва та інші. Характерним для таких об’єктів $\epsilon$ великий об’єм приміщень та великі витрати теплоти на вентиляцію. В такому випадку виникають задачі комбінування як верхніх (опалення та вентиляція), так і нижніх джерел енергії з використанням, як додаткового джерел, теплоти вентиляційних викидів

В цьому напрямку було розроблено комбіновану схему для опалення та вентиляції об'єкта 3 використанням теплоти вентиляційних викидів та грунту. Проведено термодинамічний аналіз такої схеми, на основі якого зроблені висновки щодо зменшення питомих затрат зовнішньої енергії на систему опалення і вентиляції та пониження стартових капітальних затрат на виготовлення і монтаж теплового насоса і грунтового теплообмінника.

(C) М.К. Безродний, С.О. Ословський, 2018 